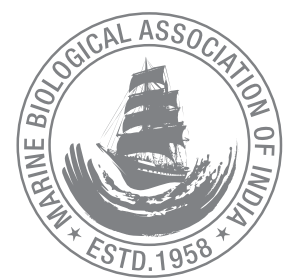

\title{
New distributional record of Ragged Sea Hare, Bursatella leachii Blainville, 1817 along western Bay of Bengal
}

\author{
P. R. Behera ${ }^{1 *}$, M. A. Jishnudev ${ }^{2}$, Ponnaganti Shiva ${ }^{1}$ and Shubhadeep Ghosh ${ }^{1}$ \\ ${ }^{1}$ Regional Centre of ICAR-CMFRI, Visakhapatnam, Andhra Pradesh - 530003, India. \\ ${ }^{2}$ ICAR-Central Marine Fisheries Research Institute, Kochi, Kerala- 682018, India. \\ *Correspondence e-mail: beherapralaya213@gmail.com,
}

Received: 26 Oct 2019 Accepted: 07 Dec 2020 Published: 10 Dec 2020

\begin{abstract}
Thirty specimens of Bursatella leachii (Ragged sea hare) of average total length as $30.93 \mathrm{~mm}$ and weight as $3.33 \mathrm{~g}$ were collected from marine cage site, Ramakrishna beach, Visakhapatnam and Krishna estuary, Nagayalanka along Andhra Pradesh coast during July, 2017 and June, 2019. A literature review on the distribution of this species revealed that, this is the first report of Bursatella leachii from the coast of Andhra Pradesh. Earlier it was recorded from the south east coast and west coast of India. This report provides a new distributional record of the species along western Bay of Bengal. A note on the morphological features of this specimen is detailed in this paper.
\end{abstract}

Keywords: Andhra Pradesh, bursatella leachii, range extension, aplysiidae

\section{Introduction}

Nudibranchs are gastropod molluscs that can easily be identified based on their shell-less bodies and a pair of rhinophores on the dorsal side of the head. These organisms are commonly called as 'butterflies of the ocean' because of their striking coloration. Globally, 3000 species of Nudibranchs have been recorded (Willan and Coleman, 1984). Out of which, 311 species have been reported from India (Vishal and Deepak, 2013). Among nudibranchs, Bursatella leachii Blainville, 1817 is commonly known as Ragged sea hare belonging to the family Aplysiidae and the order Aplysiida. This is the only species described under the genus Bursatella. The distribution of this species has generally been reported from the temperate waters of the Indo-Pacific and Atlantic Oceans and also from Mediterranean Sea (Zenetos et al., 2003; Daskos and Zenetos, 2007).

The species is commonly inhabits in intertidal and sub-tidal sheltered bay, estuarine areas with sand or muddy bottoms, seaweed bed, seagrass and mangrove habitat and occasionally in harbour environments (Lowe and Turner, 1976; Sethi et al., 2015). It is a benthic detritivore commonly found grazing on the surface layers of muddy and sandy bottoms of protected bays and estuaries. It can grow more than $10 \mathrm{~cm}$ in length. This is a hermaphroditic species with a very fast life cycle and continuous reproduction. Like other sea slugs, this is chemically protected from most wild predators by the presence of ink glands which secrete noxious or unpalatable compounds. Many researchers have earlier reported other related species belonging to the Opisthobranch fauna from India. This species, $B$. leachii has 
been earlier reported from Mumbai, west coast of India (GBIF, 2019) and Pulicat lake, south east coast of India (Sethi et al., 2015). This is the first record of the species along north east coast of India and provides a new distributional record of the species along western Bay of Bengal.

\section{Material and methods}

During regular biodiversity survey at marine cage site at Ramakrishna beach, Visakhapatnam and at Krishna estuary, Nagayalanka along Andhra Pradesh coast, we have noticed huge numbers of sea slugs entangled on cage net and spread in water around the cages during July, 2017 and June, 2019 respectively (Fig. 1). The specimens were collected (Fig. 2) and brought to the laboratory for detailed taxonomic investigation. All measurements were recorded with a digital Vernier caliper to the nearest $0.1 \mathrm{~mm}$ and total body weight was recorded to the nearest $0.1 \mathrm{~g}$ using an electronic weighing balance. The collected specimens were preserved in $70 \%$ Ethanol and deposited in the marine biodiversity museum, Regional Centre of ICAR-Central Marine Fisheries Research Institute, Visakhapatnam.

\section{Results and discussion}

\section{Systematics}

Phylum : Molluscs

Class : Gastropoda Cuvier, 1795

Order : Aplysiida Lamarck, 1809

Family : Aplysiidae Lamarck, 1809

Genus : Bursatella Blainville, 1817

Species : Bursatella leachii Blainville, 1817

Material examined: Twenty eight specimens, July 2017, coastal water, Ramakrishna beach, Visakhapatnam $(17.714082 \mathrm{~N}, 83.323611 \mathrm{E})$, coll. P. R. Behera, depth $10 \mathrm{~m}$, marine cage site; Two specimens, June, 2019, Krishna estuary, Nagayalanka (15.939941N, 80.914344E), coll. Shiva, depth: $8 \mathrm{~m}$; Estuarine cage site.

Description: The body is compact with distinct head and neck regions. The color of the dorsal side of the body is whitetan with dark brown blotches and scattered bright blue spots (Fig. 3). The numbers of blue spots on body were found in the ranges of 9 to 11 . The body is also covered with numerous long, branching fleshy white papillae that give the animal its ragged appearance. The head bears four tentacles: two olfactory tentacles called rhinophores originating on the dorsal part of the head and two oral tentacles, near the mouth (Fig. 3). The gill is covered by a pair of fleshy parapodia. The ventral side of the animal was white in color (Fig. 4). The present observation revealed that an internal shell is completely absent in adults

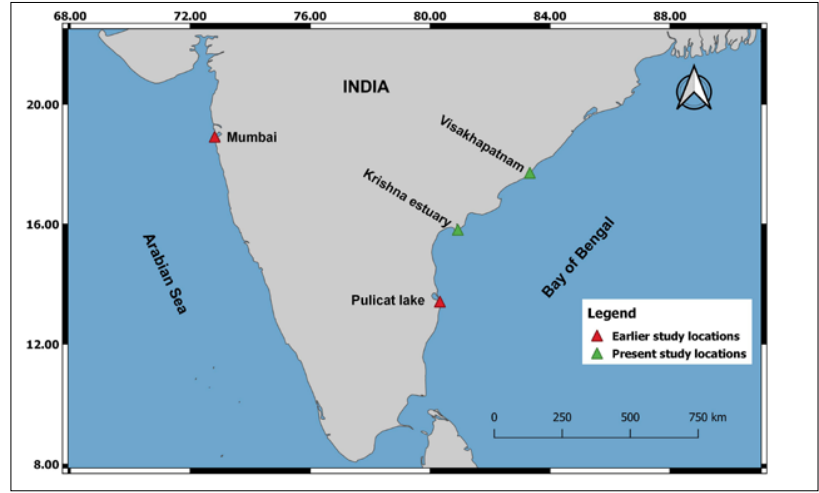

Fig. 1. Map showing the distribution of Bursatella leachii along the Indian coast

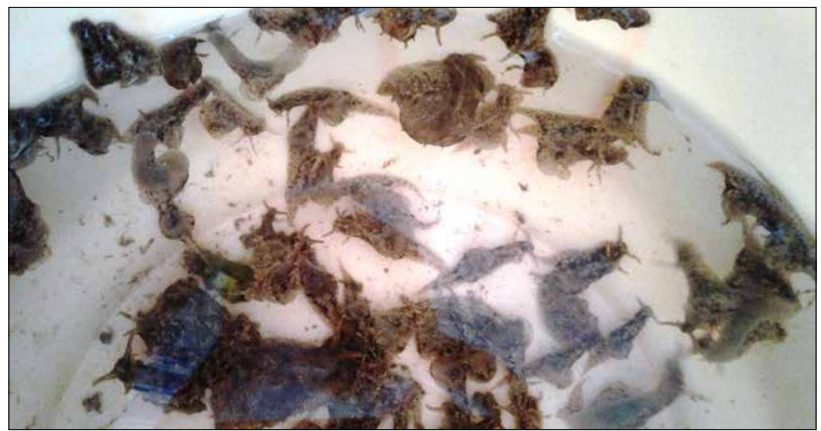

Fig. 2. Freshly collected specimens of Bursatella leachii from cage site

like earlier authors reported (Voss, 1980; Kaplan, 1988; Rupert and Fox, 1988). In the present study, the average total length and weight of the specimens recorded were $30.93 \pm 1.34 \mathrm{~mm}$ and $14.10 \pm 0.74 \mathrm{~g}$ respectively. The average total body width recorded was $3.33 \pm 0.22 \mathrm{~mm}$ (Table 1). Similarly, Sethi et al. (2015) have reported the maximum length and weight of the species from Chennai coast were $75 \mathrm{~mm}$ and $23 \mathrm{~g}$ respectively. While studying the distribution of lessepsian ragged Sea hare along the coast of Mediterranean, Turkey, Ozvarol (2014) has reported the maximum size of the species as $150 \mathrm{~mm}$. Clarke (2006) has recorded the size range of the species as $30-50 \mathrm{~mm}$ from northeast Queensland, Australia.

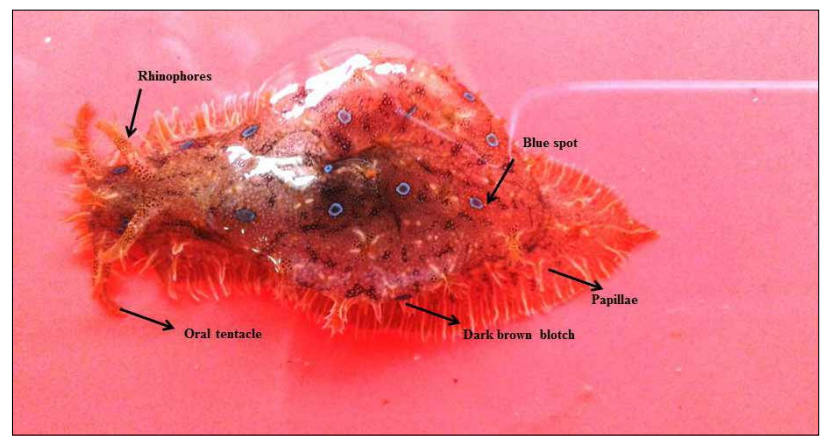

Fig. 3. Dorsal view of Bursatella leachii 


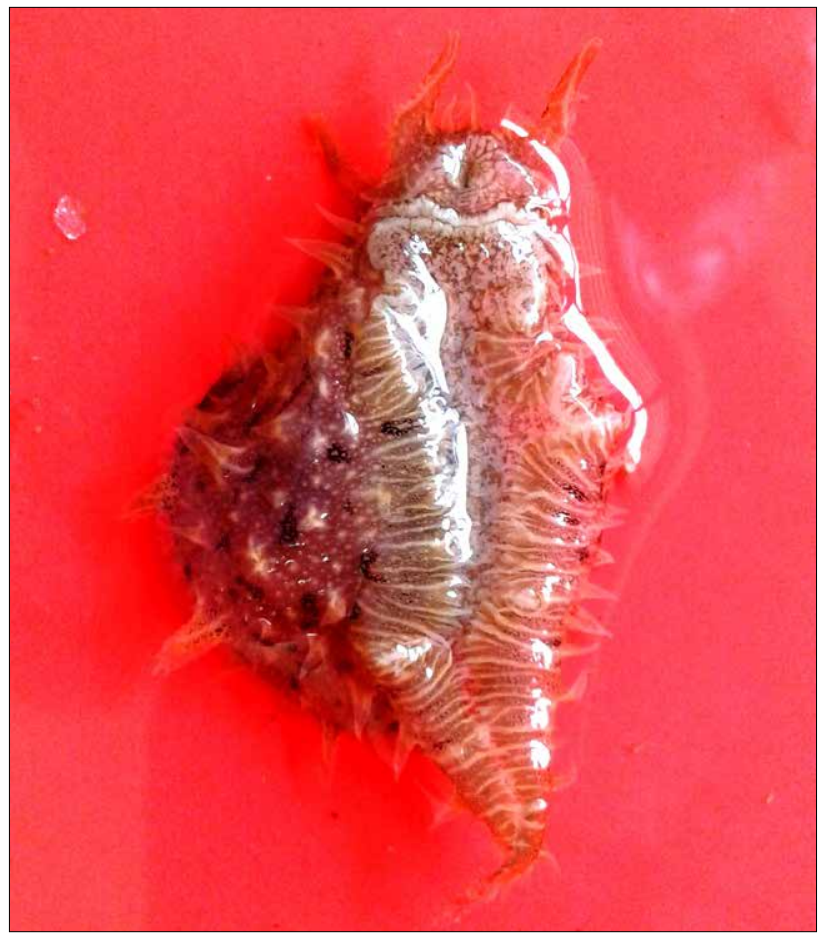

Fig. 4. Ventral view of Bursatella leachii

Table 1. Morphometric characteristics of Ragged Sea Hare, Bursatella leachii

\begin{tabular}{llllllll}
\hline $\begin{array}{l}\text { Sl. } \\
\text { no. }\end{array} \begin{array}{l}\text { Total length Total } \\
(\mathrm{mm})\end{array}$ & $\begin{array}{l}\text { Body width Sl. } \\
\text { weight }(\mathrm{g})\end{array}(\mathrm{mm})$ & $\begin{array}{l}\text { Total length Total } \\
\text { no. }\end{array}$ & $\begin{array}{l}\text { Body width } \\
\text { weight }(\mathrm{g})(\mathrm{mm})\end{array}$ \\
\hline 1 & 46 & 20 & 6 & 16 & 29 & 15 & 2 \\
\hline 2 & 43 & 21 & 4 & 17 & 28 & 10 & 2 \\
\hline 3 & 37 & 15 & 3 & 18 & 30 & 12 & 2 \\
\hline 4 & 38 & 19 & 3 & 19 & 30 & 14 & 2 \\
\hline 5 & 43 & 22 & 4 & 20 & 27 & 10 & 1 \\
\hline 6 & 31 & 13 & 2 & 21 & 26 & 13 & 1 \\
\hline 7 & 44 & 23 & 4 & 22 & 24 & 12 & 1 \\
\hline 8 & 41 & 20 & 4 & 23 & 20 & 9 & 1 \\
\hline 9 & 42 & 18 & 4 & 24 & 22 & 12 & 1 \\
\hline 10 & 29 & 13 & 2 & 25 & 23 & 11 & 1 \\
\hline 11 & 35 & 18 & 3 & 26 & 21 & 10 & 1 \\
\hline 12 & 26 & 11 & 2 & 27 & 25 & 11 & 2 \\
\hline 13 & 28 & 16 & 1 & 28 & 26 & 10 & 2 \\
\hline 14 & 29 & 11 & 1 & 29 & 24 & 10 & 1 \\
\hline 15 & 32 & 12 & 2 & 30 & 29 & 12 & 2 \\
\hline Mean & SE $30.93 \pm 1.34$ & & $14.10 \pm 0.74$ & $3.33 \pm 0.22$ \\
\hline
\end{tabular}

Remarks: The present study showed the occurrence of the species both in estuarine as well as coastal marine water. The density of occurrence of the species at cage site in coastal water was found as high as 150-200 numbers/ $\mathrm{m}^{2}$. Similarly, Rudloe (1971) has reported the occurrence of very high densities of greater than 600 individuals per $\mathrm{m}^{2}$ and negatively affect the commercial shrimp farming. Hence this occurrence in variety of habitats suggests a moderate tolerance for salinity fluctuations. This species has good demand in small aquarium trade. The ink gland of the species is being used for preparation of pharmaceutical products. Kamiya et al. (2006) have reported a number of antimicrobial or cytotoxic proteins from $B$. leachii and other sea hares. Appleton et al. (2002) isolated a novel bioactive malyngamide from $B$. leachii of New Zealand. Rajaganapathi et al. (2002) have reported that protein present in purple fluid of Sea Hare with anti-HIV properties. It is believed to be capable of sequestering secondary metabolites from the algae it feeds on (Capper et al., 2005).

\section{Acknowledgements}

The authors are grateful to the Director, ICAR-Central Marine Fisheries Research Institute, Kochi for his encouragement and support. The help rendered by the Head, Marine Biodiversity Division, ICAR-CMFRI for the study is heartfully acknowledged.

\section{References}

Appleton, D. R., M. A. Sewell, M. V. Berridge and B. R. Copp. 2002. A new biologically active malyngamide from a New Zealand collection of the sea hare Bursatella leachii. J. Nat. Prod., 65: 630-631.

Blainville, H. M. D. de. 1817. Dictionnaire des Sciences Naturelles (F. Cuvier, Ed.) 5: 138 pp. Capper, A., I. R. Tibbetts, J. M. 0. Neil and G. R. Shaw. 2005. The fate of Lyngbya majuscule toxins in three potentials consumers. J. Chem. Ecol., 31:1595-1606.

Clarke, C. 2006. The population dynamics and feeding preferences of Bursatella leachii (Opisthobranchia: Anaspidea) in northeast Queensland, Australia. Rec. West. Aust. Mus. Suppl., 69:11-21.

Daskos, A. and A. Zenetos. 2007. Additions to the knowledge of the alien Opisthobranchia of Greece. Aquat. Invasions, 2(3): 258-260.

GBIF. 2019. Bursatella leachii Blainville, 1817, In: GBIF Backbone Taxonomy. Checklist dataset https://doi.org/10.15468/39omei accessed via GBIF.org on 2019-10-17

Kamiya, H., R. Sakai and M. Jimbo. 2006. Bioactive molecules from sea hares. Prog. Mol. Subcell. Biol., 43:215-239.

Kaplan, E. H. 1988. A Field Guide to Southeastern and Caribbean Seashores: Cape Hattaras to the Gulf Coast, Florida, and the Caribbean. Peterson Field Guide Series. Houghton Mifflin Company, NY. 425 pp.

Lowe, E. F. and R. L. Turner. 1976. Aggregation and trail-following in juvenile Bursatella leachii plei (gastropoda: Opisthobranchia). Veliger, 19:153-155.

Ozvarol, Y. 2014. The distribution of the lessepsian ragged sea hare, Bursatella leachii de Blainville, 1817 (Aplysiidae) in the Mediterranean coast of Turkey. J. Fish. Sci., 8 (4): 298-302.

Rajaganapathi, J., K. Kathiresan and T. P. Singh. 2002. Purification of anti-HIV protein from purple fluid of the sea hare Bursatella leachii de Blainville. Mar. Biotechnol., 4: 447-453.

Rudloe, J. 1971. The Erotic Ocean. Thomas Y. Crowell Co., NY. 448 pp.

Rupert, E. E. and R. S. Fox. 1988. Seashore Animals of the Southeast. A Guide to Common Shallow-Water Invertebrates of the Southeastern Atlantic Coast. University of South Carolina Press. $429 \mathrm{pp}$.

Sethi, S. N., S. Otta and G. Sethi. 2015. First record of Ragged Sea Hare, Bursatella leachii Blainville, 1817 (Opisthobranchia: Euopisthobranchia: Aplysiidae) in Pulicate lake, East coast of India. Mar. Biodivers. Rec., 8: e34.

Vishal, B. and A. Deepak. 2013. Current Status of Indian Opisthobranch Fauna. In: Venkataraman K., C. Sivaperuman, C. Raghunathan, (eds) Ecology and Conservation of Tropical Marine Faunal Communities. Springer, Berlin, Heidelberg. p. 63-79.

Voss, G. L. 1980. Seashore Life of Florida and the Caribbean. Dover Publications, Inc., NY. 199 pp.

Willan, R. C. and N. Coleman. 1984. Nudibranchs of Australasia, Australasian Marine Photographic Index, Caringbah, Sydney, $56 \mathrm{pp}$.

Zenetos, A., S. Gofas, G. Russo and J. Templado. 2003. CIESM Atlas of Exotic Species in the Mediterranean, (3): Molluscs, edited by F. Briand. Monaco: CIESM Publishers, $376 \mathrm{pp}$. 